\title{
The Role of Social Media in the Recent Political Shifts in the Middle East and North Africa
}

\author{
Farhad Rezaei ${ }^{1}$, Ronen A. Cohen ${ }^{2}$ \\ ${ }^{1}$ Mr. Farhad Rezaei is a PhD Candidate in International Relations, Department of Strategy and Security \\ Studies, Faculty of Arts and Social Science, UM, Malaysia. \\ ${ }^{2}$ Dr. Ronen A. Cohen is an Assistant Professor for Islamic and Iranian Studies, Department of Middle Eastern \\ and Israel Studies, Ariel University Center, Israel
}

\begin{abstract}
This paper intends to demonstrate the significant role played by the social media during the last several years and in the outbreak of recent revolutions and social protests in the Middle East and North Africa which have led to deep systemic changes. The role played by Facebook and Twitter was considerable during the turmoil and uprising that helped citizens overthrow the dictators that governed them in Egypt and Tunisia and assisted in the spreading of sensitive information in the national context of what happened in Iran, Syria, Yemen, Saudi Arabia and Libya. Thus it appears that the digital media is making real political shifts possible. After reviewing the literature, we describe how social medias assisted in the downfall of tyrannical regimes in the Middle East and North Africa.
\end{abstract}

Key Words: Social Media, Middle East, North Africa, Political Shifts, Revolutions, Social Protest. 'Most of the scholars and politicians like Marx, Lenin and Stalin believed that sooner or later capitalism will be destroyed, but the systems that allow their opponents to criticize will never fall'.

\section{Introduction}

Sadegh Zibakalam

In recent decades a large number of countries with all kinds of totalitarian political systems such as monarchies, oligarchies, military dictatorships, one-man government have moved into the camp of democracy. While most of the world's countries have altered their political systems two regions have still remained unchanged: the Middle East and North Africa. Despite other countries rushing forward the Arab world, including the Middle East and North Africa, has literally stuck to its guns as countries from the Persian Gulf to North Africa have employed all the methods at their command, like force, to stifle dissatisfaction and retain power. These countries were quite thriving and a large amount of scholarship arose to explain the phenomenon of "authoritarian persistence" in the Middle East and North Africa but, ultimately, their extreme rigidity called them to account Revolutionary idealism turned into the vicious pessimism, financial growth slowed down and promising republics turned into "family kleptocracies". Many events occurred in the region over the years, but nothing changed that much. (Council on Foreign Relations and Staff). Surprisingly, in the recent months the Middle East and North Africa started a course of explosive political turmoil different from any these areas had observed before. This was escalated by a strong combination of wrath, disappointment, expectations and promise, and people took to the streets in order to overthrow the Arab regimes. Therefore, connected by virtue of their moderns and internet tools, their determination for "direct action (which) hearkened back to revolutions" has found its inspiration from the past years. (Satloff, 1993, Robert Satloff, 2011 )

The new prospects became available because of the virtual space for political expression, communication and political perspectives offered by the internet and there is an obvious reason for the migration of political dialogue into the virtual space. In practically all of the Arab states in the Middle East and North Africa films, books and the media are under the control of a brutal regime which extremely limits freedom of expression. However, what consequences on real-life politics this "free-wheeling political dialogue" has in virtual space is a question that one must think about. (Murphy, 2009)

Long lasting social ills, such as suppression from the top and political and economic dissatisfaction from below, are the major reasons for the protests and turmoil in the North African and the Middle Eastern countries; but also important are the high rates of unemployment (particularly among the young), dissatisfaction over political corruption, corporate greed in the financial sector as well as general disappointment with the political condition. (ŞEN and Bölümü-Elazığ, 2012). The success of the revolutions in the ME\&NA is beginning to change the region's perspective and people's determination to look for freedom and democracy on their own terms. (Ghannam, 2011)

Even though many of the Arab countries, especially Saudi Arabia, Syria, and Tunisia, have determined what websites can be seen in their countries or monitor people who are online, the virtual social media has become an important tool for the citizens to reach beyond the boundaries of the state-controlled press. (Albright et al., 2005) 
It is important to note that the traditional media have also played an essential role in the protests in the region. Arab satellite channels broadcast a wide coverage of the turmoil relying on satellite dishes throughout the Arab world. In fact, political activists "credit a triangulation" of media with effectively notifying the populace about events and mobilizing them. A good deal of the content from the revolution released in the traditional media originated on Facebook. Activists collected content, like video and photos, from Facebook pages and YouTube in order to post it on other platforms and translate it into various languages. (Ghannam, 2011)

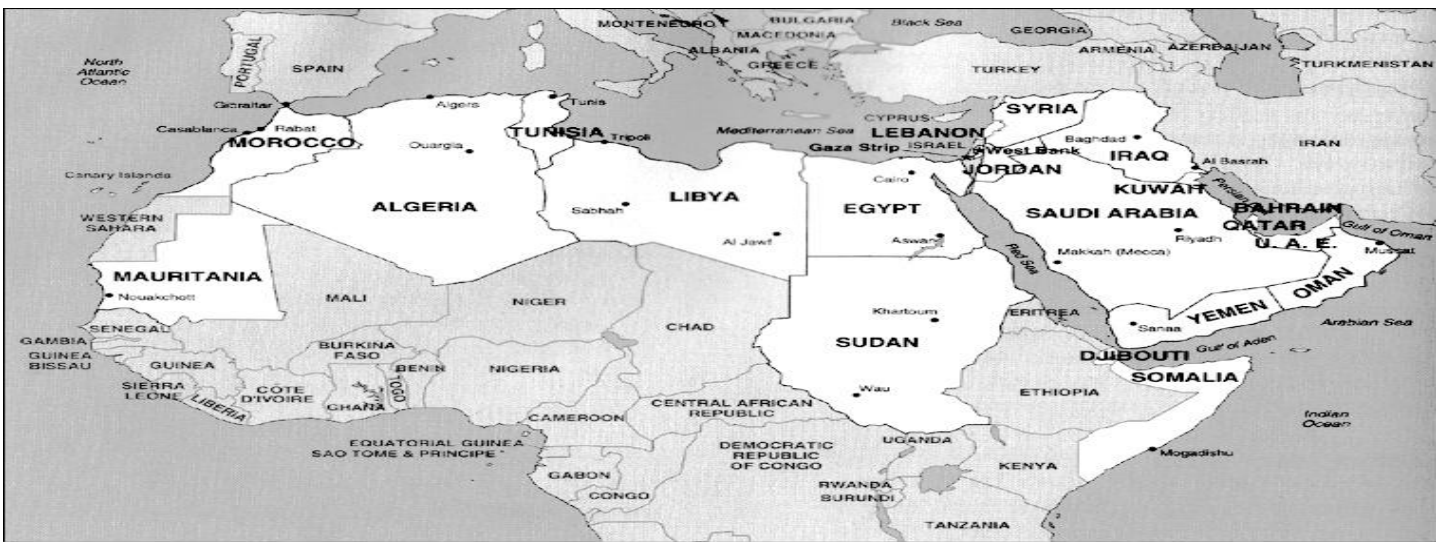

Source: $\underline{\text { http://www.dod.gov/pubs/prolif/me_na.html }}$

Arab leaders have long acknowledged the danger caused by the social media and have made efforts to control virtual space activities by establishing filters and limitations. The continuing role of the social media in Middle East politics seems assured. Approximately half of the populace of Iran, Yemen, Oman, Saudi Arabia, Jordan, Morocco and Egypt are under the age of 25 and they seem to be leading the Middle East into a new order, enabled by the technologies they know best. Social media is chronicling and strengthening the revolution that is happened on the streets. In fact, as Jeffrey Ghannam noted "if the pen - or the click - is mightier than the sword, then social media and mobile technology represent a new and welcome way forward".(Ghannam, 2011)

\section{Scope:}

The study focuses on the period of starting protests in the Middle East and North Africa from the June 2009 presidential elections in the Islamic Republic of Iran to the present time.

\section{Objectives:}

The aim of this research is to present the significant effects of the new media on the politics in the area, notably in the countries under tyrannical systems in which the social media do not have freedom of action and are banned by the brutal governments. This paper has four sections: 1. A discussion of the Media's role in politics; 2. Specifically a description of the history of the media's role in the Middle East; 3.A demonstration of the role of the social medias in the recent political turmoil in the region; and4. A discussion section that will deal whether or not these alterations in the political systems of those countries have satisfied the aspirations of the citizens.

\section{Source Of Data}

For the sake of gathering the needed data related to rate of citizen's access to internet, we used the electronic archival data provided by INTERNETWORLDSTATS. Other sources have been gathered from the library resources, internet web pages, newspapers and magazines.

\section{The Role Of Media In Politics}

What role do the powerful new media play in politics? The short and long term effects cannot be denied but do the new media offer us any political information or simply entertain us for profit and ratings?

The media have found their niche in today's politics and via talk shows, television and the internet have laid a foundation and built a platform from which to voice their social agendas and flex their political muscles. One thing is for sure, if you want to succeed in politics, it doesn't hurt to have the media on your side.

Sometimes, in the United States, the mass media system experiments with serious transformations that signal that they have reached a new plateau in its progress and pervasive recognition of the role of the new media in politics occurred during the 1992 presidential campaign when the presidential candidates decided to utilize radio and television talk shows, news magazine programs and the internet. 
In this way the TV media rapidly enhanced their position in the political process and the political elites and the conventional press could not help but take them seriously. A criticism levied against the television media was that they overshadowed serious matters of governing by combining entertainment with politics so that political issues could now be analyzed daylong on cable news. As Ross Howard stated, "Campaigns had to give a second look at the role of media in politics. The media could be a tool of support or a thorn in your side." (Howard, 2003)

The Internet is one of the greatest tools that can be used against censorship. Bloggers can get information out within seconds using either Twitter, Facebook, personal blogs or reporting in little videos that are afterward shared on YouTube. Increasingly, the internet has become a tool for political communications as well. On the net you can now obtain political information, express political opinion and mobilize other voters and political leaders; and you can also make political donations. In a brief time, the web has grown into a major player in the new media. The Obama campaign was one of the first presidential campaigns to include the internet and many of us still regularly receive updates through Twitter but President Obama also knows that there is a second campaign to be and therefore his tools have remained well-established and are kept functional.

\section{Media In The Middle East And North Africa}

The history of the press in the Middle East stretches back to the early years of the nineteenth century when western missionaries brought the first presses with movable type to the Middle East, and the governments used the new technology to publish official information and to pass on news and entertainment. By the end of the twentieth century newspapers started to be published in Egypt, Iraq, Algeria, Tunisia, Syria, Yemen, and Sudan.

Government ownership of the press was not the rule in every Arab country and in some of them governments worked out understandings with local, private publishers which allowed them to function as long as they were generally loyal to government policies.

There were significant exceptions to the general pattern of having the media serve the state. Lebanon, with its extraordinary mix of ethnic and religious groups, that denied any one group majority status, developed a tradition of having a free press and this enhanced tolerance for a diversity of attitudes but this was different from the other part of the Middle East and the Arab world. Starting with the permission of the French, and enduring well beyond, the Lebanese viewpoint was that the presence of a diversity of magazines and newspapers would represent all Lebanese life, opinions and aspects.

Unfortunately, the Lebanese civil war caused most of the Lebanese intellectual community to flee into exile and a large number of the writers and editors sought refuge in foreign countries where many rebuilt the publications they had constructed in Beirut and some built new ones.

Nowadays censorship exists in the print media in many forms, from removing offensive articles from newspapers to prohibiting printed materials and governments are able to censor the broadcast media by jamming standard radio and television programs. Presumably, the most severe censorship in some countries has taken place with the case of audio cassettes and videotapes sent through the regular mail. Mindful of the fact that that the Islamic revolution in Iran in 1979 was supported by smuggled-in cassettes of Ayatollah Khomeini's sermons, some Arab governments carried out complete reviews of recorded materials before releasing them to his followers later. There are four reasons in general for censorship in the Arab world including the Middle East and North Africa. The primary reason has to do with the bounds of political debate. Even though there is some degree of free debate in each Middle Eastern country, there are some "taboos" and lines that cannot be crossed and these red lines often have to do with Islamist opposition groups. The second, and related, red line is criticism of a country's rulers or their relatives. In most countries, political cartoons depict only low ranking political figures because depicting the leaders in a critical light is so clearly out of bounds. A third redline has to do with writing of a religious nature that might cause agitation in the country while the fourth red line has to do with sexual and social traditions. As with religious debates, the boundaries of debate vary from country to country. (Alterman, 1998)

\section{Satellites In The Arab World}

One of the recent innovations that has taken place in the Middle East and Arab world over the last decade is satellite television. In fact, in most of the Arab countries and in the Middle East television itself is less than a few decades old. Egypt began television broadcasts in the early 1960s and Yemen did not start TV broadcasting until the mid-1970s. From the beginning Arab television was strictly controlled by state broadcasting authorities. Its news programs were seriously scripted and almost regularly led to widespread coverage of the head of state's activities. Nowadays satellite dishes have expanded across the Middle East and North African countries and, even though an appraisal of their exact numbers is impossible, close observers of the satellite scene estimate that two-thirds of the Persian Gulf population has access to satellite television. 
Some events that have taken place in the Arab world have led to the emerging of satellite television in the 1990s. The primary development was the multilateral response to Iraq's invasion of Kuwait where, to a large extent, "Operation Desert Storm" and its previous events in 1990-1991 made for breathtaking television programming. The Pentagon public relations experts discovered the significance of public opinion on the performance of the war and, even though the conflict was not a "made-for-TV movie," it supplied highly exciting images for news broadcasts. The outcome was a sense of immediacy and steady massive information for TV spectators. The second essential development was the launch of a new generation of satellites that led to the sudden emergence of satellite TV in the Arab world. The third significant development was the emergence of a substantial class of Arab experts who had studied in the West before returning to their home countries. (Alterman, 1998)

The media plays a great role in the life of human beings both individually and as a mass. According to Ross Howard, "Media here refers to the several mediums or channels used in an organized fashion to communicate to groups of people".(Howard, 2003) The media can have the effect of changing the knowledge, values, and attitudes of people. It is considered to be one of the most effective tools used to motivate people and promote relations among societies on a large variety of issues. Wherever and whenever violent conflict looms, the media have an essential role to play. They can provoke the situation; or they can use their considerable power to reduce tension. In other words, they can be part of the problem, or they can be part of the solution. Practically, they are usually both. (Howard, 2003) The policies of the media relate to every global area and affect political, economic, security and social conditions - which means the media has a wide scope for interaction between the powers in every country. The effective role of the media is also emphasized during times of conflict where the broadcasting of pictures and news stimulates people and create a kind of psychological warfare. The media serves as a source of information for both citizens and political elites. At the same time it is used as a tool to influence and create public opinion that takes either an opposing or affirming position on a certain issue. The media is a double-edged sword, and the way it is used depends on the parties who have control of it. As Howard notes: "The news media is a curious instrument. It can be a weapon of war, or can uphold prospects for peace". (Howard et al., 2003) The role of the media on the global level acts as a tool to set a worldwide agenda. With extensive audience outreach, their coverage can escalate or de-escalate conflict and serve as a channel of communication between leaders and antagonists. (Bajraktari and Parajon, 2009) In the Middle East, the media is much more controlled by the governments than in other parts of the world and active censorship is widespread. At the same time there are some main players in the region who set the agenda but on the local level the media can play a role in achieving community building and trust, and can be used as a tool to achieve peace. According to Christina Pajaron, "local media can contribute to peace merely by restoring levels of trust and self-worth in a population on the brink of or emerging from violence". (Bajraktari and Parajon, 2009)

One example is the media's function on all stages during the 1979 Islamic Revolution in Iran and following provides some particularly remarkable insights into the nature of media performance throughout phases of public stress. By looking at the Iranian case, it can clearly be seen that, even though the media underwent a substantial shift in their direction and functions from October 1978 to July 1979, the fundamental quality and nature of their functioning following the revolution, under the Islamic republic, is functionally similar to what existed under the shah's government - although it has significantly altered qualitatively. Prior to the revolution the press, radio, and television mainly functioned as organs which supported the state's principal ideology at the time - specifically, Iranian nationalism as reflected in the institution of the monarchy and its extensions in the form of the Iranian government. Television and radio programming were mainly ordered on the basis of the outlook of social and political leaders who felt they were providing the society with cultural materials that would eventually prove to be beneficial. For the duration of the revolution, the media reversed its position to full opposition of the ideology represented by the monarchy as well as to the monarchy itself.

On the other hand, once the Islamic regime had been formed the media returned to its role of backing the dominant state ideology introduced by Ayatollah Khomeini. This time, however, the leading ideology was that of the Islamic Revolution. Censorship, newspaper closings, arrests, and intolerance of critical opinion continued in a fashion almost similar to that which existed during the shah's government.

Newspapers, which used to be overwhelming in their flattery of the monarchy, were in all issues now full of repeated glowing references to the "revolutionary clergy." It is now a crime to offend a clergyman and journalists have been detained for doing this. The shah's pictures on the front page were replaced with those of major religious/political figures. It is reported that figures like Ayatollah Hashemi-Rafsanjani criticize the newspapers when their pictures are missing from the front page for several days running. Some of the press activity after the revolution was continued with a degree of public support. At a public gathering in Tehran a few days after the abdication of Shahpour Bakhtiar, these sentiments were expressed: "Whatever the leaders of the revolution do it is for a good reason, so one shouldn't question it." "No one should be allowed to express opinions that will hinder the progress of the Revolution." "Anyone who writes that television and radio are 
censored is obviously a supporter of the CIA and only wants to dishonor the Revolution." The foreign press, radio and television were extremely controlled in their operations under the shah's government, due in part to incompetence in the conduct of their operations. Currently their operations are officially and highly restricted under the Islamic regime. For better or worse, intentionally or not, their role in Iranian life occupies the same minimal space it did before the revolution. (Beeman, 2008)

There is closeness that exists in the relationship between democracy and the media. From this perspective the function of the media is seen as something that provides society with reliable information on which they can make political choices, essential for democracy (Woodier, 2008). This is a significant consideration given that 'modern political practices are made possible through mediated political communication in most democratic societies'. There have been detractors who suggest the media performs poorly in this role and that election coverage is superficial and overdramatized - yet the link between the media and politics is unshakeable. Voters in modern societies find political information from the media and the news media have a direct impact on political activity and participation since they are closely connected to political knowledge. (Woodier, 2008)

Through repeated news coverage the media are able to establish the importance of certain issues in the public's mind and that, while the media might not directly affect how the populace thinks about political issues, it does affect what subjects people think about, thereby establishing what political issues people consider important (Severin and Tankard, 1992). Along with the abovementioned media the growing use of the internet, computers and phones has also driven a growth in the amount of information people generate and use. As with the printing press the internet does not only spread media consumption but media production as well and allows people to individually and publicly articulate and debate a welter of conflicting views. Social media tools are not a replacement for real-world action but a way to coordinate it.(Shirky, 2011)

Few people can deny that the social media have enabled the most considerable progress in freedom of expression and association in current Arab life and, throughout the turmoil, the social media have aggregated, disseminated and expedited crucial news and information. In the end, however, Facebook and YouTube are tools - and tools alone are unable to bring about the changes the world has witnessed in the last few months. With a large number of unemployed Arab populations, that are marginalized and feeling powerless to change their futures under totalitarian governments that have been increasingly out of touch, all the elements for turmoil were there. The social media helped make the grievances all the more urgent and difficult to ignore. In fact the best practical reason to think that the social media were able to help bring about a political change is that both opponents and governments think they can. All over the world, activists believe in the value of these tools and as a result take steps to utilize them accordingly. And the regimes they contend with think social media tools are influential too and so are willing, in response, to harass, seize, expel or destroy those who use them. (Shirky, 2011).

\section{Post-Mass Media: The Technology Knowledge Revolution Service}

The media scene into which these generations are maturing is changing. If, once, the signature communicative relationship of the mass media revolution in the Middle East was reception then, today, under a regime of one-to-many senders to receivers or mass audiences for state monopoly broadcasters, the counterpart of post-mass media is more interactive communication in which the senders multiply and social distance between senders and receivers diminishes. This is caused by a confluence of an increasingly up-market populace with down-market technologies. The dramatic example of this, not recognized at the time that the Ayatollah Khomeini was delivering his sermons and other banned religious figures were circulating theirs via cassette in pre-revolutionary Iran, has not only been the popular circulation of sermons today but has also been joined by recordings of folk music, pirated commercial recordings and, in periods of revolution, "night letters" (shab-name) as the originally written versions were called. These technologies are linked to each other as was demonstrated in the case of the delivery of Khomeni's sermons via telephone from France a generation ago or the mix of amateur and pirated commercial material in any cassette-shop today. Convergence is happening on the street and in homes. But now things have changed quite a lot and currently in the Middle East models for structuring and providing access to the broadcast media are applied to the internet. Much initial concern over the internet in the region has focused on 'culturally inappropriate" content, from those in positions of authority of all sorts from heads of state to religious spokesmen and heads of families. (Anderson, 1999)

The significance of the internet as a model for new media is to bring new people into the political sphere into which the values and experiences of those who build this space are built. This is a space of new identities - and some have experimented with outside traditional confines. In this context Facebook YouTube and Twitter are said to be extremely popular because of the opportunities for role-playing as well as for communication that is otherwise restricted in 'real life', such as is the case with gender differences. More consequentially a range of potential political successors is emerging with savvy in and commitment to new media models such as those used for industrial development. (Anderson, 1999). 


\section{Internet In The Middle East And North Africa}

The expansion of the internet in order to obtain more information and communication has enhanced civil society, democracy and political participation and has generated social movement. The social media have made easy and cheap communication among people available and have played a vital role in such movements notwithstanding the fact that the media in general may have ignored the subject of the protest. Within the Arab world most opinion leaders are men and, historically, females do not take part in political discourse. The internet has resolved this problem and provided freedom and opportunity for the women to express their ideas. Bloggers and Facebook activists may often be unable to speak in the real world but are passionately engaged in online activities. As Professor Fulya Sen has stated "the co-existence of different public spaces (offline and online) allows more people to speak out and disseminate ideas to influence their networks - in other words to become opinion leaders. For social movements this means that their ideals can be spread faster and to more people which, in turn, widen the opportunity for social and political change." Fulya adds: "The horizontal communication structure, which is provided by social media, can thus foster social movements and as a result social change. Social media provide activists from all over the world the means to coordinate activities, exchange best practice examples and gain attention for their cause." (ŞEN and Bölümü-Elazı̆̆, 2012) Nowadays in almost every Arab and Middle Eastern country the internet is accessible, and the number of users increase every day. Al-Hayat runs a full page on computer topics every Thursday. The PC newspapers and Magazine's Middle and Near East edition sells large numbers of copies. Daily newspapers maintain pages through the internet pages, some of them post the full text of their daily editions and only one charges for the privilege of reading this. A large number of Arab and Middle Eastern regimes are also establishing an existence on the worldwide web. (Alterman, 1998) Satellite-based telephone services, along with the internet, which are outside the control of individual nations, primarily give security to private communications between people and are less effective in reaching mass audiences.

Middle Eastern regimes have tried to install themselves as an obstacle between their people and information. Wireless TV systems and government-based internet systems have been part of such endeavors but as the growing amount of information in the world is targeted at increasingly narrow audiences, Middle Eastern and Arab regimes may well find that an attempt to prohibit their people from being exposed to foreign ideas is a meaningless task. The amount of information passing back and forth will prevail over any tools installed to control that information. (Alterman, 1998)

\section{Internet Accessibility Of Citizens In The Middle East And North Africa}

One of the most recent estimates of internet usage in the Middle East in 2011 claims that there is a total of 72,497,466 internet users as of June 30/11 ( 33.5\% of the Middle East population) and 16,125,180 Facebook users on June 30/11 (7.5\% penetration rate). Among Middle Eastern countries, Israel is the biggest user with about 5,263,146 total users as of May/08, (70.4\% penetration) out of a population of only 7,473,052 million. More than 70 percent of Israelis are online and, as of June/11, there are 3,442,680 Facebook users (46.1\% penetration). They are followed by Iran with a population of 77,891,220 (2011) - with 36,500,000 users as of June/11 (46.9\% penetration, per IWS). The third Middle Eastern country is the United Arab Emirates (UAE) with a population of 5,148,664 (2011) with 3555100 estimated users and 2,340,880 Facebook users on June $30 / 11$ (45.5\% penetration). Syria comes next with a 22,517,750 population (2011) and 4,469,000 users as of Mar/11 (19.8\% penetration, per ITU). Then there is Yemen with 24,133,492 population (2011) and 2,349,000 users as of Mar/11 (9.7\% penetration, per CIA) and 329,040 Facebook users as of June 30/11 (1.4\% penetration). Saudi Arabia comes next with a 26,131,703 population (2011) and 11,400,000 users as of Dec/10, (43.6\% penetration, per CITC) and 4,034,740 Facebook users as of June 30/11 (15.4\% penetration).

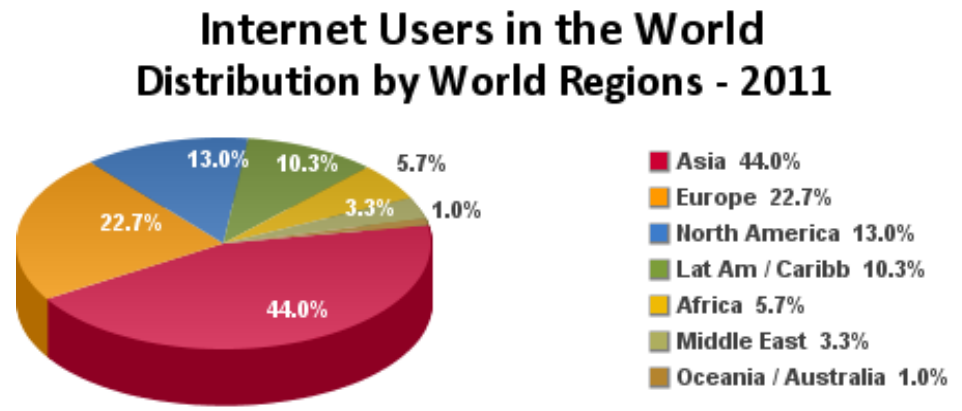

Source: Internet World Stats - www.internetworldstats.com/stats.htm

Basis: 2,095,006,005 Internet users on March 31, 2011

Copyright @ 2011, Miniwatts Marketing Group

http://www.internetworldstats.com/stats1.htm 
If one estimates 2,095,006,005 million internet users worldwide in March 2011, the Middle East as a whole contains 3.3 percent of the world population of internet users, and the North African countries 1.3percent.

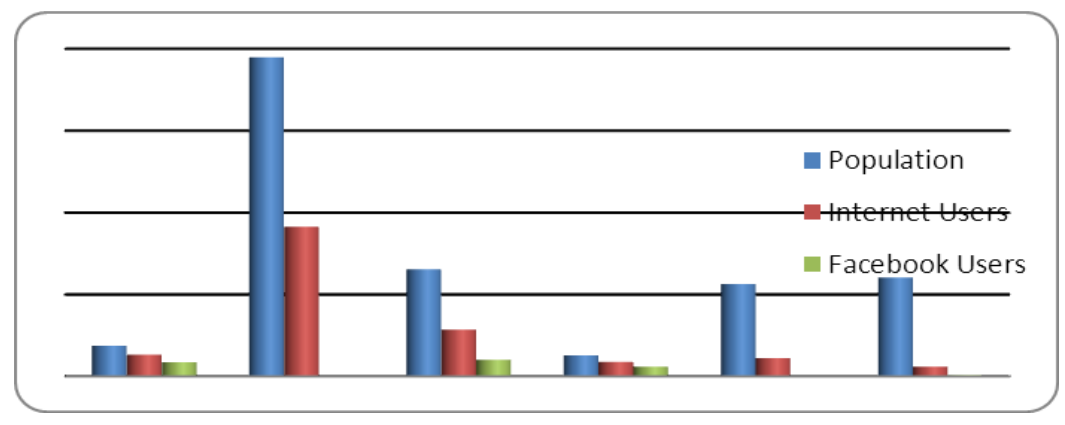

Among the countries of the North Africa, there is Egypt with a 82,079,636 population (2011) and 20,136,000 Internet users as of Dec/10 (24.5\% of the population, per ITU) and 7,295,240 Facebook users on June 30/11, (8.9\% penetration rate) Next is. Libya with a 6,597,960 population (2011) and 353,900 internet users as of Jun/10 (5.4\% of the population, per ITU) and 52,860 Facebook users on June 30/11(0.8\% penetration rate). Next is Tunisia with a 10,629,186 population (2011) and 3,600,000 Internet users as of Mar/10, (33.9\% of the population, per ATI) and 2,602,640 Facebook users on June 30/11 (24.5\% penetration rate).

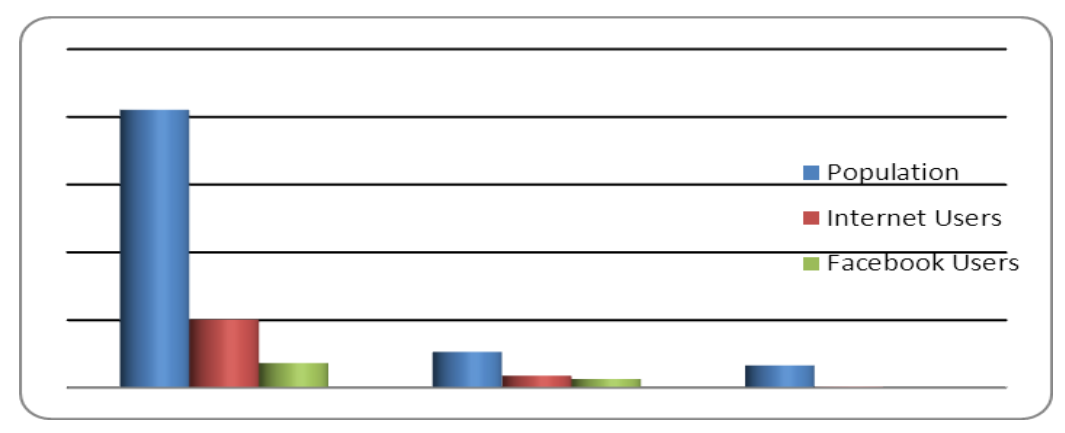

\section{The Role Of Facebook, YouTube And Twitter In Middle East And North Africa}

As turmoil sweeps through the Middle East, some companies have found themselves central to the action in an unprecedented way. Google, Facebook, YouTube and Twitter are all confronting the kind of moral and political dilemmas that global corporations usually hope to avoid. Their differing reactions tell us a lot about their corporate values - in a deeper sense than that issue is usually talked about. Google's response has been the most exemplary. From its earliest days Google has asserted an unusual claim to ethical behaviorwith its slogan "Don't Be Evil." The company has, on occasion, shown itself willing to forgo profits and take risks that others wouldn't to avoid violating its own principles.(Weisberg, Feb. 24, 2011).

Facebook is playing an essential role in the revolts that have overthrown governments in Tunisia and Egypt and have caused uprisings in Syria, Yemen, Libya and Iran. The popular social networking site is becoming more than just a cyber-meeting place but has grown into a powerful tool for political and social alteration. Facebook offers a "virtual" platform for the development of political and social causes and is quickly turning into a hotbed of "actual" activism - a cause for alarm for many autocratic regimes in the Middle East who are attempting to block it and curtail its reach. Other social media tools like YouTube and Twitter also played major roles in revolts in the Tunisia, Egypt, Iran and Syria. Facebook was the major tool used in Egypt and was the first to share reports about police abuse and then build an online community that was mobilized to join the 'Jan. 25 protests'. (Boms, June 26, 2008) Protesters gathered in many places around Cairo and this made efforts to control them. They misled the police by announcing a gathering and then rapidly changing locations and alerted demonstrators to new sites set up by Twitter. (G, 24 February 2011) The Egyptian government blocked Facebook and found new methods to check, censor, slow down or, when they felt eventually threatened, shut down the internet totally and cut the country's link to the worldwide internet almost completely. Mubarak's downfall after three decades of rule showed what the power of social media sites including Facebook, Twitter and mobile phone technology was. (Ghannam, 2011)

Similarly, the Assad government in Syria has mobilized an "electronic army" to go on a violent offensive against the growing opposition there and this represents the latest iteration of the government's attempt to add internet access suppression to their repression tool kit (Çağaptay, August 7, 2011 ). They blocked Facebook due 
to an anti-regime, e-mail spam campaign channeled through the site and a law has been drafted to regulate online media requiring them to register and submit what they write to government review.

In the Persian Gulf countries a more sophisticated censorship system has tried to ban only the more threatening Facebook and Twitter applications and other Web sites such as video content, photographic images and computer based phone services. (Boms, June 26, 2008)

Iran's Political opposition to the outcome of the presidential election has expanded not only in the streets of Tehran's but also in the virtual space where protesters against Ahmadinejad and observers of the election have battled to get news out of the country for three days. Through the Facebook Iranian Citizen professing neutrality provide a platform for information that reports alleged abuses and brutality by the government. A typical posting, from June 7, 2010, reported: "The Islamic Republic is preparing another round of mass executions in an effort to terrorize the Iranian people into submission in advance of the one-year anniversary of the ongoing Iranian uprising.(Meyer, December 16, 2010)

As the violence escalated in the streets of Tehran one short video, less than a minute long, became particularly haunting. The video was terrible as it showed a young girl dying on the street following being shot by a Basiji (Khamenei's loyal army) who placed a bullet in her heart. Neda, the girl, died with her arms outstretched above her head and her eyes fixed open, as if staring into the camera, as blood began surging from her mouth and nose, while those people who came to her relief pleaded hysterically for her to stay alive. Shocked witnesses tried in vain to revive her. Immediately after the video was posted on the Internet, the image of Neda dying was seen worldwide. The image became iconic, coming to symbolize the pain Iranian people felt protesting in the streets for their liberty against a vicious government determined to repress the protests by all means and at all costs. Acknowledging the effect of the video in attracting anger the government prohibited Neda's family from holding a funeral in public. Still, Ayatollah Khamenei showed no signs of backing down, as the protest violence threatened to become not just a call for reelection but a threat to the existence of the regime itself. In the meantime, the Basij and Sepah-e-Pasdaran Corps started to post videos and images of the protesters on its website, with individual protesters being hunted down for detention by dividing them from the crowds with circles placed around their faces like targets. The Basij militant asked Iranians loyal to the regime to turn in their fellow citizens whom they recognized as traitors for their protests in the streets where they challenged the election's reliability and the authority and legitimacy of the Ayatollah Khamenei to announce the victor. (Corsi, 2009)

The government tried to control the flow of information to and from news organizations among protesters about the supposed results of that nation's presidential election and has sought to block access to Facebook since the protests that followed President Mahmoud Ahmadinejad's contested victory in the 2009 election took place (Siebert, June 15, 2009 ).

Twitter, made history in Iran and the media across the globe have been focusing on a "Twitter Revolution" in Iran as hundreds of thousands of street protestors purportedly mobilized their demonstrations using the microblogging service.(Schectman, 2009) However, Iran experts and social networking activists say that while Iranian election protesters have certainly used social media tools, no particular technology has been instrumental in the organizers' ability to get people onto the street.(Schectman, 2009) Indeed one of Twitter's primary contributions in the Iranian elections has been the raising of awareness about the issue among techsavvy users outside the country. (NEWS, June 16, 2009) .

Trita Parsi, an expert on Iranian-American relations has noted that the "candidates for president decided to use social networking sites in the campaign after noticing how effective they were in the U.S. presidential election". He said that "it was not surprising that Twitter was popular given how much Iranians distrust official media sources. Iranian officials have tried to jam Twitter and Facebook, but Iranians are figuring out how to hack through these filters. These efforts have been dismal failures". Parsi acknowledged that "Facebook and Twitter were important mainly for letting people outside the country follow events, and text messages and phone calls were the primary mover of people in Iran's protests." "The people I know mainly tell me they hear about these protests from friends or by SMS," (NEWS, June 16, 2009) "On the street level, people are asking themselves, 'What's going on. What does the candidate want us to do?' Well, you go to Facebook and you check what is the latest status line of your candidate, and from there they could find out what was actually taking place." (NEWS, June 16, 2009)

Facebook has taken steps to help protesters in Tunisia after government officials used a virus to obtain local Facebook passwords during the uprising. The company rerouted Facebook's traffic from Tunisia and used the breach to upgrade security. It was careful to cast the response as a technical solution to a security problem.(Preston, 2011)

In Egypt, Google went even further by directly opposing an oppressive government. When Mubarak cut off internet access, the company developed a workaround that allowed users to send Twitter messages over phone lines. YouTube, which Google owns, also created a hub to promote videos from protestors in Tahrir Square. In fact, Google has walked a fine line on this point providing tools to help undermine tyranny without directly 
embracing any particular group of revolutionaries. Facebook's platform played the bigger role in Hosni Mubarak's downfall as well.

Twitter goes a step beyond even Google in its sense of anti-authoritarian mission. Where Google's core value is freedom of information, Twitter expounds the slightly different one of freedom of expression. As with the others Twitter's attitude reflects its culture - one that is unconventional, insurgent and even at times mildly irresponsible. As a smaller, more freewheeling company that has postponed maximization of profits in favor of growth and experimentation it has the latitude to embrace not just liberal principles but specific challenges to authority. (Weisberg, Feb. 24, 2011)

'The Arab Spring is a movement seeking democracy, freedom of the press, freedom of election and the rule of law, Even though the Islamists are among its opponents the main intention of the Arab movements is only democratic freedom.'

Sadegh Zibakalam

\section{Discussion:}

The social media have had an important role in the turmoil that has taken place in the Middle East and North Africa but one must never overlook the fact that, as the these region's history shows, every revolution has brought about a worse reality for the people, one that is completely different from the slogans that promised a new and prosperous future. As a result a host of countries are transforming themselves into radical Islamic states instead of constructing the promised Western-style democracies expected by the western countries including the United States and European countries.

In some countries, like Libya, there has been a total alteration--Qadhafi has been overthrown, and leadership has passed to a group comprising both jihadists and bureaucrats. In Egypt, the alteration is worryingly insignificant -- Mubarak has been expelled from office but the military rulers who have succeeded him have reestablished his atrocious "emergency laws" and continue to drag political activists before military tribunals. Similarly, in Tunisia, they are still trying to recover from the forced revolution that has, apparently, not helped the population to release themselves from neither the tyranny nor from the current situation. The members of the 'mob' that was forced to participate in these "revolutions" are still rethinking the motivations and aims that caused them to protest. The immediate conclusion that can be made is that, despite the precious advantages these electronic tools have provided, there are important disadvantages that might bring the revolutions to an end. A revolution, by its very nature, essentially and entirely changes the current order and replaces it with a new one - a change of 180 degrees. In order to bring about this change and to break the old political, social, financial and army elites (that exist in every country, and notably in the Middle Eastern and North African countries) these revolutionaries should take into consideration a few essential components for the creation of revolutions.

First - there are no official or unofficial oppositions, and those who have tried to take advantage of the chaos have crashed into the rocks. Second - there is no manifesto or systematic treatise that can be presented to the people but only the empty slogans that could be posted on Facebook walls but not in the minds of the people. The revolutionaries have only one target - to bring down and topple the current regimes, but without thinking about the day after and designing a real future. Last but not least - the term "spiritual leaders' does not only mean the clerics but also authors, intellectuals and philosophers, whose main power is their world point of view and their words.

In the Facebook generation any blogger and post writer can be considered to be "the leader" of the revolution, but can such a leader be considered to be a political leader? Has he had any experience with a political system and agenda? Probably - NO. The missing component in these spiritual leaders is the absence of the spiritual foundations of the revolution that might be remembered for generations and could be rooted in the hearts of the people. With all due respect to the importance of the mass media and electronic media a revolution needs leaders, spiritual manifestos and an organized opposition. Without these basic components, and only using even the ultimate digital tools, it's hard to see any revolutions being successful in the future.

Certainly, the citizens of the region need the assistance of western countries in order to establish democracies after the downfall of the dictators. The international community should do the same for the Middle Eastern counties as the Americans did for the Philippines against Marcos, the Yugoslavs against Milosevic, and the Czechs, Hungarians, and Poles against the Soviet Empire. The United States and Europe are also able to do much more to encourage freedom of speech and democracy. The United States' policy toward the enhancing of democracy in the Middle East and North Africa must be based on emphasizing the significance of the free media and access to it.. Without free media that can act as a watchdog, democracy in the Middle East and the Arab world cannot be established and the United State must continue to emphasize access as a central theme. A country like Iran hosts the third-largest blogging community in the world and they must have access to digital cameras and other equipment like the wireless internet on their cell phones. Because the authorities shut down the cell phone network during turmoil, student leaders need to have satellite phones. Iranian satellite networks 
based in Los Angeles and elsewhere can also play a crucial role because of their immunity from the threats of the Iranian regime.

\section{Conclusion:}

In recent times the media have been dominated by revolutions all over the Middle East and North Africa. In recent years, in the "Arab and Islamic world", a region largely dominated by tyrannical governments and dictators, the opposition movements have been able to prevail over the dictators and overthrow the tyrannical governments or, at least, have been able to initiate their downfall. What is known as the "Arab Spring" in the Middle East and North Africa is the product of an extremely active opposition that has developed over a long period.

The "Arab Spring" has presented us with a new point of view since, for citizens living under tyrannical regimes, the internet is the heaven of freedoms. As events in Egypt, Tunisia, Iran, Syria, Libya and Yemen have confirmed, the social media provide the opposition to these regimes with the capability to implement freedoms that were earlier unavailable to them. The social electronic media offers the medium through which political freedoms for the first time in human history are within the reach of everyone. Therefore it is time to consider the internet as the first freedom of the 21 st century, the first step to all other kinds of freedoms. Without Facebook or Twitter, or even the internet itself, the revolutions could hardly have occurred. What is truly encouraging about all of this is that as the internet spreads even into dictatorial countries, it will be far more difficult for tyrants to brainwash their people.

There is a close relationship between democracy and the news media. In this perspective, the function of the news media is seen as providing society with reliable information based upon which they can make the political choices essential to democracy. The significance of the internet, and of the internet as a model for new media, is to bring new people into the political sphere and into a sphere in which the values and experiences of those who build this space are built in. Because of the shadow cast by the social media despotism is an unacceptable method of governing in the contemporary world.

\section{Notes:}

[1] ALBRIGHT, M. K., WEBER, V. \& COOK, S. A. 2005. In support of Arab democracy: why and how: report of an independent task force, Council on Foreign Relations Press.

[2] ALTERMAN, J. B. 1998. New media, new politics?: from satellite television to the Internet in the Arab world, Washington Institute for Near East Policy Washington, DC.

[3] ANDERSON, J. W. 1999. Technology, media, and the next generation in the Middle East. New Media and Information Technology Working Papers.

[4] BAJRAKTARI, Y. \& PARAJON, C. 2009. The Role of the Media in Conflict.

[5] BEEMAN, W. O. 2008. The" Great Satan" vs. the" Mad Mullahs": how the United States and Iran demonize each other, University of Chicago Press.

[6] BOMS, N. June 26, 2008. OP-ED: Facebook in the Middle East". The Washington Times A.

[7] ÇAĞAPTAY, S. August 7, 2011 Internet Freedom Is the First Freedom of the 21st Century. Available: http://www.washingtoninstitute.org/templateC06.php?CID=1693.

[8] CORSI, J. R. 2009. Why Israel Can't Wait: The Coming War Between Israel and Iran, Simon and Schuster.

[9] COUNCIL ON FOREIGN RELATIONS, I. \& STAFF The New Arab Revolt: What Happened, What it Means, and What Comes Next, Council on Foreign Relations.

[10] G, I. C. 24 February 2011 Popular Protest in North Africa and the Middle East (I): Egypt Victorious?” International Crisis Group

[11] GHANNAM, J. 2011. Social Media in the Arab World: Leading up to the Uprisings of 2011. Center for International Media Assistance/National Endowment for Democracy, 3.

[12] HOWARD, R. Year. The media's role in war and peace-building. In, 2003.

[13] HOWARD, R., PREVENTION, E. C. F. C., GROUND, E. C. F. C., INSTITUTE FOR MEDIA, P. \& SOCIETY, C. 2003. The power of the media: A handbook for peace builders, European Centre for Conflict Prevention.

[14] MEYER, E. L. December 16, 2010. By the People: The Rise of Citizen Journalism Available: http://cima.ned.org.

[15] MURPHY, C. 2009. Arab Facebook: The Internet's Role in Politics in the Middle East. The Majalla, 13.

[16] NEWS, C. June 16, 2009. Twitter emerges as news source during Iran media crackdown

[17] PRESTON, J. 2011. Facebook Officials Keep Quiet on its Role in Revolts. The New York Times.

[18] ROBERT SATLOFF. 2011 Between Protests and Power, Middle East Change and US interests" Available: http://www.washingtoninstitute.org/templateC04.php?CID=348.

[19] SATLOFF, R. B. 1993. The politics of change in the Middle East, Westview Pr.

[20] SCHECTMAN, J. 2009. Iran's twitter revolution? Maybe not yet. Business Week, 17.

[21] SEN, A. P. D. A. F. \& BÖLÜMÜ-ELAZı Ğ, İ. F. G. 2012. THE SOCIAL MEDIA AS A PUBLIC SPHERE: THE RISE OF SOCIAL OPPOSITION.

[22] SEVERIN, W. J. \& TANKARD, J. W. 1992. Communication theories: Origins, methods, and uses in the mass media, Longman New York.

[23] SHIRKY, C. 2011. The political power of social media. Foreign Affairs, 90, 28-41.

[24] SIEBERT, M. June 15, 2009 Iran Protesters Using Tech To Skirt Curbs [Online]. CBSNews. Available: http://www.cbsnews.com/stories/2009/06/15/earlyshow/leisure/gamesgadgetsgizmos/main5088668.shtml [Accessed].

[25] WEISBERG, J. Feb. 24, 2011. The Arab Revolt shows that Google's and Twitter's corporate values are better than Facebook's Slate. Available: http://www.slate.com/id/2286432/.

[26] WOODIER, J. 2008. The media and political change in Southeast Asia: karaoke culture and the evolution of personality politics, Edward Elgar Publishing. 